Article

\title{
Floristic Diversity and Cultural Importance in Agroforestry Systems on Small-Scale Farmer's Livelihoods in Central Veracruz, México
}

\author{
Sjoerd Pietersen ${ }^{1}$, Juan Carlos López-Acosta ${ }^{2, *}$, Jorge Antonio Gomez-Díaz ${ }^{3}$ \\ and Maite Lascurain-Rangel ${ }^{3}$ \\ 1 International Land \& Watermangement M.s. Wageningen University \& Research, \\ 6708 Wageningen, The Netherlands; sjoerd.pietersen@gmail.com \\ 2 Centro de Investigaciones Tropicales, Universidad Veracruzana, Xalapa, 91000 Veracruz, Mexico \\ 3 Red Ambiente y Sustentabilidad, Instituto de Ecología, A.C., Xalapa, 91070 Veracruz, Mexico; \\ jorge.gomez@inecol.mx (J.A.G.-D.); maite.lascurain@inecol.mx (M.L.-R.) \\ * Correspondence: jcarlos1975@yahoo.com
}

Received: 29 December 2017; Accepted: 16 January 2018; Published: 22 January 2018

\begin{abstract}
México is a cultural and biological megadiverse country with an increased anthropogenic pressure on its tropical landscapes. The study area was the ejido "Los Ídolos", Misantla, Central Veracruz, Mexico. The main objective of this research was to identify how the woody plant diversity of agroforestry systems contributed to the cultural, economic, and subsistence security of local farmers. Five different agroforestry systems were identified: forest gardens (FG), home gardens (HG), plantation crop combination with perennial cultivates (PC), plantation crop combinations with annual cultivates (AC), and trees on pastures (TP). FG systems had the highest floristic diversity, followed by HG and TP. Interviews with farmers showed that FG, HG, and PC systems were important for maintaining cultural identity and secure subsistence needs, while PC and TP systems were important for improving the economic situation of farmers. The FG systems contained only native species, while the proportion of exotic plants differed among the other systems. Useful exotic plants were found in the HG system. This study demonstrated that agroforestry systems such as FG were not used to their full potential, despite their high diversity of useful plants. It is recommended that farmers-assisted by institutions and representatives of local product chains-conduct feasibility studies on the marketing and promotion of products derived from specific agroforestry systems.
\end{abstract}

Keywords: importance value index; native woody plant species; ethnobotany; tropic; plant conservation

\section{Introduction}

México is a country with diverse heterogenic landscapes reflecting the presence and anthropogenic history of the contrasting socio-economic development of many cultures within a time span of a few thousand years [1]. However, natural landscapes in Mexico are currently in threat by rapid antropogenic changes such as deforestation, inadequate land tenure regulation or the intensive agricultural and livestock farming to produce products for human consumption [2]. However, these landscapes still have the potential to fulfil a broad range of ecosystem services and functions to satisfy the needs of local, national, and global involved stakeholders [3].

The direct causes of the deforestation rates are interrelated and complex [4]. In the case of México, increased conflicts over land tenure and foreign and local policies that marginalized the economic position of farmers in the past, are the current causes of deforestation. Many farmers overexploit available natural resources (often due to market pressures) which affect their well-being in the long-term [5]. With reference to the Mexican rural population, the World Bank concluded that 
more than 16.9 million peasants (63.6\% of the rural population) lived below national rural poverty lines [6]. Together, indigenous farmers occupy $14.3 \%$ of the total land surface in México [5] and are generally considered as the poorest group of land dwellers [7].

As described above, México has witnessed increased anthropogenic pressure on the remaining tropical landscapes. Expansion of human activity caused an irreversible, unalterable transformation of its natural ecosystems with cultural consequences caused by a loss of traditional knowledge with respect to usable plant species associated with these ecosystems [8].

One way to lessen the processes of loss of cultural and biological diversity in rural areas is to develop practical approaches to identify, evaluate, and provide hands-on tools to counteract these processes at a local level. Therefore, recognizing and learning from local management can protect native flora within the systems that are important to well-being. By this way, all types of forest management systems represent a particular degree of management intensity: from the uncontrolled gathering of natural forest products to the intensive management of domesticated tree crops in monoculture plantations [9]. Between these two extremes, hundreds of site-specific intermediate agroforestry exist [10]. Eventually, most of the character and appearance of an anthropogenic landscape results in a mosaic of different land use types that occupy a transitional position between monoculture agriculture and natural forests [11-14]. This transitional position of agroforestry systems depends on local subsistence strategies aiming to increase the presence of valuable plant species maintained by the local population according to their socio-economic and cultural needs. Nevertheless, this may differ significantly on a local scale [9].

When the management procedures are not limited to slash and burn methods, most of the plant and animal diversity which remains in these transformed landscapes are relatively well conserved, mostly by indigenous farmers in México [15]. Their limited economic resources require them to maintain a diverse range of plant species to satisfy basic economic and subsistence needs. Next to these needs, several authors have emphasized the role of agroforestry systems as a strategy for biodiversity conservation $[9,14,16]$. Hence, agroforestry systems have been recognized for their high potential to reconcile productive purposes with the conservation of biodiversity and ecosystem services [11].

Common property regimes may contribute to environmental conservation and offer a model that can limit land use and enable natural and cultural capital conservation of these regions [17]. The ejidos in Mexico, (collective landholdings) which are defined as an extended system of common land parcels collectively managed by peasants, can strengthen land tenure security and improve the efficiency of rural and credit markets [18]. Currently, 51\% of the territory of México is under this form of land ownership. The area of each ejido varies, but the national average is 2156 ha with a surface area of 9.5 ha by owner $[19,20]$. Specifically, in the state of Veracruz, $40 \%$ of its territory is under the regime of common land, but with smaller areas called ejido (about 600 ha each). Usually, the ejido are inhabited by people with a high cultural association with their environment, with the majority of mestizo people dedicated to small-scale land use practices.

In this study, we focused on the description of the agroforestry systems within a representative ejido of the southern state of central Veracruz México named "Los Ídolos". We focused on the characterization of the link between woody flora and their contribution to subsistence and the cultural identity of local farmers. Therefore, the main goals of our study were: (i) to classify and map the agroforestry systems in "Los Ídolos"; (ii) to identify, using both the scientific literature and local knowledge, the role of woody plant species (exotic and native) and the contribution to the subsistence and cultural needs of farmers found in the local agroforestry systems; and (iii) to identify a set of provisional cultural ecosystem services, qualifying the previous classified agroforestry systems. 


\section{Materials and Methods}

\subsection{Study Area}

The study area was in the ejido "Los Ídolos" (19 $52^{\prime}$ and $21^{\circ} 02^{\prime} \mathrm{N}$ and $96^{\circ} 46^{\prime}$ and $\left.97^{\circ} 59^{\prime} \mathrm{W}\right)$, in Central Veracruz, Mexico, a municipality of Misantla. This ejido covers 239 ha, is characterized by anthropogenic elements in the landscape, and consists of different types of agricultural land (Figure 1). The elevation ranges from $360 \mathrm{~m}$ to $630 \mathrm{~m}$. It is situated at the Sierra de Misantla, which has a diverse topography dominated by a mountainous landscape with a gradual increase in elevation from sea level along the Gulf of Mexico (1).
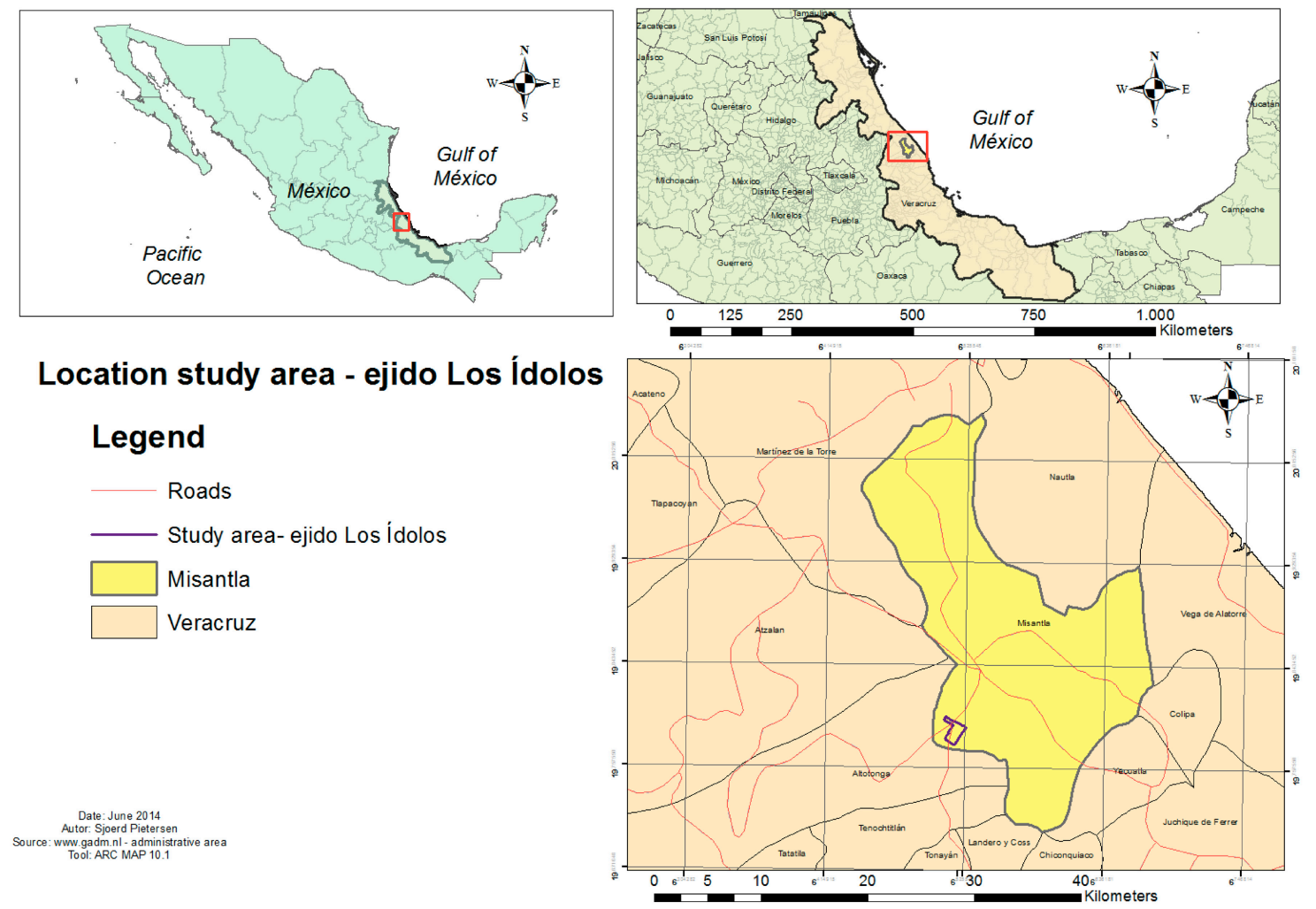

Figure 1. Location of the study area.

The ejido is currently inhabited by nearly 400 people, grouped into 150 families who use the surrounding land for several agricultural purposes such as shade-grown coffee plantations, citrus plantations, maize and bean cultivate, pastures with scattered trees for livestock, and regularly logging high value timber species. Furthermore, for their subsistence, the peasants collect fruits, nuts, bark, firewood, fibers, medicinal, and construction material products from a wide range of tree species [21].

\subsection{Landscape Description}

The collected field data on land use and vegetation agroforestry systems were classified according to the structural system classification of Nair [10]. Agroforestry systems were first categorized on their management type (Figure 2) and were subsequently subdivided into the following three main groups: (1) agro-silviculture systems: crops (including shrubs/vines) and trees; (2) silvopasture systems: pastures, animals, and trees; and (3) agro-silvopasture systems: crops, pastures, animals, and trees. Subsequently, a final distinction between the different agroforestry systems was made based on associated local practices. After the localization of the borders and the identification of the occurring agroforestry systems, a set of transects were established within the 'delineated' study area. The main goal of these transects was to systematically plan the identification of various 
sets of land uses and vegetation. In total, six transects of variable lengths were set out (Table A1). GPS measuring points were taken every $20-500 \mathrm{~m}$, depending on significant changes in the terrain. Moreover, we collected information about terrain access (common or private land), the intensity of forest management practices [11], and the exploitation phase of field and tree crops [9,22] using classification keys. Subsequently, we put the coordinates and additional field data in a database for their subsequent management in ArcMap 10.1 [23]. Finally, we connected the coordinate points to create new map features that resulted in a land use map of the study area.
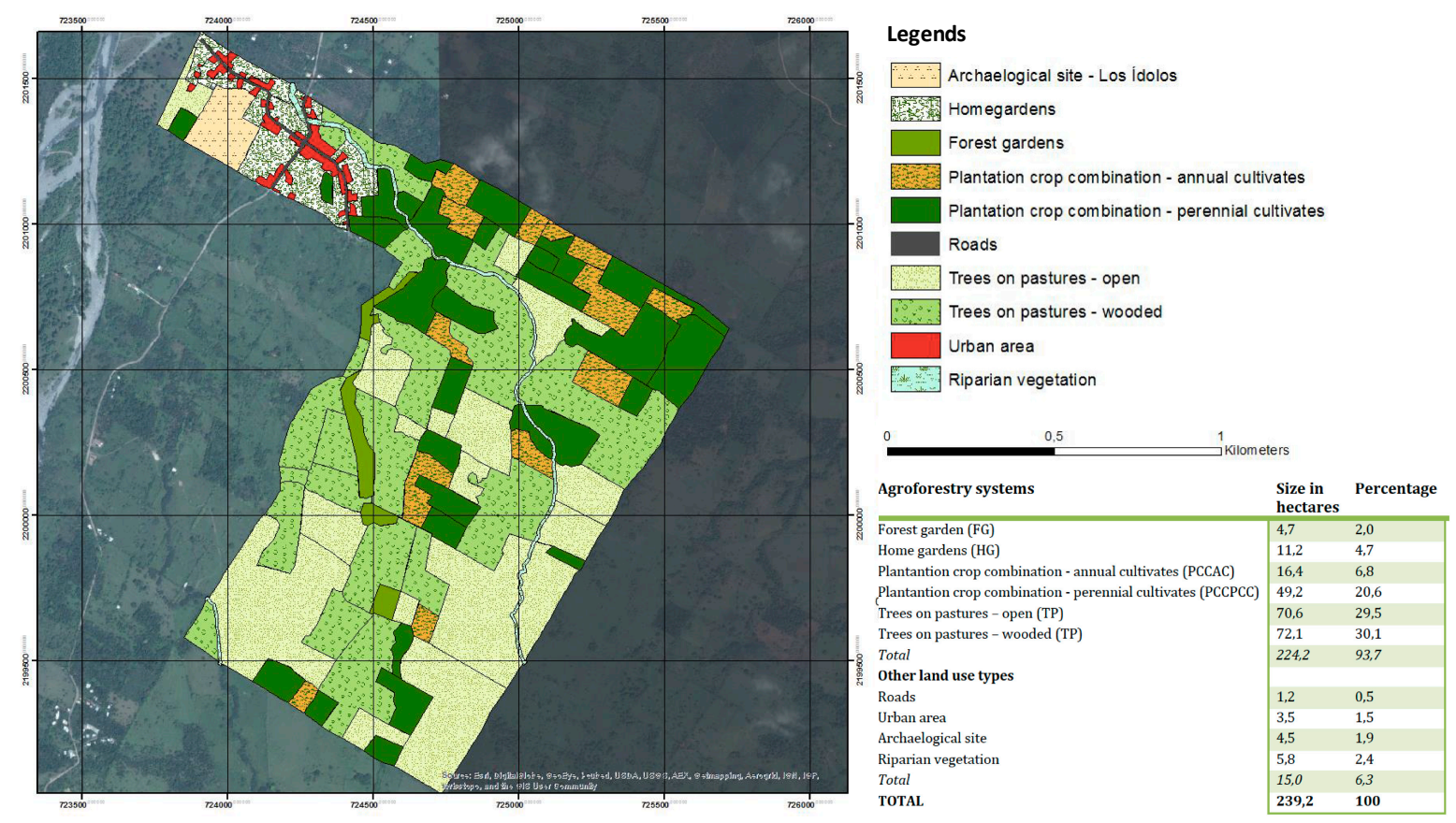

Figure 2. Location of identified local land use systems in ejido "Los Ídolos".

\subsection{Ecological Research Methods}

A sampling procedure of six transects of $2 \times 25 \mathrm{~m}$ (covering a total area of $300 \mathrm{~m}^{2}$ ) per identified agroforestry system was set up. We identified and measured all ligneous plant species in each transect that were rooted and with a diameter at breast height $(\mathrm{DBH}) \geq 1 \mathrm{~cm}$. Transects were sampled randomly, but overlap was actively avoided. The specimens were identified and deposited at the botany laboratory of the Centro de Investigaciones Tropicales (CITRO), Universidad Veracruzana. For each species, we calculated the density (D), the number of individuals $/ 1000 \mathrm{~m}^{2}$; dominance (Do), basal area of all individuals, and frequency (F), which is the number of transects where the species were present divided by the total of transects (10). We used relative values (R) for the three parameters (density, dominance, and frequency) and calculated the Value of Importance (VI): $\mathrm{IVIr}=\mathrm{DR}+\mathrm{FR}+\mathrm{DoR}$. The cumulative value for all species summed up to $300 \%$ [24].

\subsection{Social Research Methods}

We interviewed 13 of the 14 landowners available and willing to be interviewed. All fulfilled the following criteria: (i) actively managed a parcel, and (ii) had extensive traditional knowledge about (local) land use practices, tree and shrub species. To access the provisional and cultural ecosystem services of identified agroforestry systems perceived as important, farmers were asked to rank the cultural, commercial, and subsistence value of agroforestry systems on a scale of 1-10 by participatory interview [25]. Next, the average score for each agroforestry system was calculated.

To measure the subsistence proportion of plant products, farmers were asked to rank ten woody plant species that delivered the following provisional or economic ecosystem services [26]: (1) crafting 
materials; (2) food; (3) medicine; (4) construction materials; (5) shadow and fencing trees; (6) fodder; (7) firewood; (8) ornamental; and (9) reforestation species. After ranking the woody plant products, farmers were asked which agroforestry system each product was collected from and if the product was used mainly for commercial or subsistence purposes. The goal of this exercise was to generate the same type of quantitative data collected in the transects through determining the social use value (SUV) of the identified agroforestry systems. The SUV refers to woody plants used for potential commercial purposes and subsistence needs, which are based on the relative density values: the number of times a plant species for a specific use (provisional ecosystem service [27]) was collected from a certain agroforestry system, and as a percentage of the total number of all registered plant individuals perceived to be important for the economic ecosystem services above-mentioned.

To assess social plant values, suitable indices were used to collect relevant qualitative information and translate it into quantifiable data [28]. We calculated the economic and subsistence values for each species recorded [29] by applying the Relative Importance Index (RI), which measures the plant use number independent of the level of importance among the interviewed farmers [29-32]. To calculate the RI value, we first summed the number of use categories and use types of each identified species, then the RI value was calculated using the following formula:

$$
\mathrm{RI}=\mathrm{NUC}+\mathrm{NT}
$$

where NUC is the sum of use categories of a species divided by the total number of use categories of the most useful species, and NT is the number of use types attributed to a species divided by the total number of use types of the most useful species. The RI values ranged from 0 (not useful) to 2 (most useful) $[29,31]$.

\section{Results}

\subsection{Spatial Analysis of Forest Management}

We identified three main different forestry systems with distinctive associated practices in the study area (Table 1; Figure 2) that covered 94\% of the ejido's surface (224 ha).

The first category was "agro-silviculture systems" with three types of practices identified: (i) plantation crop combinations with perennial cultivates (PC) (e.g., coffee plantations, cachichinales (enriched forest of Oecopetalum mexicanum), and lemon plantations) with 49.2 ha; (ii) plantation crop combinations with annual cultivate (AC) (e.g., traditional corn plantation called milpa) with 16.4 ha, and (iii) forest gardens (FG) [33] with $4.7 \mathrm{ha}$, which represented the smallest agro-silviculture area. Together, these types of agro-silviculture systems covered approximately $30 \%$ of the ejido's surface.

The second category were silvopasture systems where "trees on rangelands or pastures" were identified as the unique practice. This practice is widely applied within in the study area and covered the largest share $(60 \%)$ within the ejido (142.7 ha).

The third category were "agro-silvopasture systems" with home garden (huerto familiar) as the only agroforestry practice, covering $5 \%$ of the ejido's surface (142.7 ha). The remaining coverage of the ejido was mostly occupied by roads and urban areas unsuitable for any kind of agroforestry/land use management with an area of 4.7 ha $(2 \%)$ within the ejido. Finally, a small portion of the ejido was occupied by an archaeological site with 0.3 ha ( $4 \%$ of the ejido's surface) (Figure 2). 
Table 1. The share of each agroforestry system and the description of the tree crop management within each agroforestry system found in the "Ejido Los Ídolos", Misantla in Central Veracruz, Mexico. The intensity of forest manipulation based on classification of Wiersum based in the intensity of forest management practices [9].

\begin{tabular}{|c|c|c|c|c|c|}
\hline $\begin{array}{l}\text { Agroforestry Practices within the } \\
\text { Study Area Ejido Los Ídolos }\end{array}$ & $\begin{array}{l}\text { Description of Tree Crop } \\
\text { Management }\end{array}$ & Major Group of Components) & Agro Ecological Adaptivity () & $\begin{array}{l}\text { Exploitation Phase of Field } \\
\text { and Tree Crops }\end{array}$ & Intensity of Forest Manipulation \\
\hline \multicolumn{6}{|l|}{ Agrisilvicultural systems } \\
\hline Forest garden & \multirow{3}{*}{$\begin{array}{l}\text { Trees, shrubs and herbaceous } \\
\text { plants are grown in a dense, } \\
\text { intimate spatial mixture, } \\
\text { partly natural forest fallow. }\end{array}$} & \multirow{3}{*}{$\begin{array}{l}\text { dense tree stand with } \\
\text { (potentiall) multipurpose } \\
\text { tree crops }\end{array}$} & \multirow{3}{*}{ In shifting cultivation areas. } & \multirow{3}{*}{$\begin{array}{l}\text { Phase 1: Uncontrolled, open } \\
\text { access gathering of } \\
\text { forest products. }\end{array}$} & \multirow{3}{*}{$\begin{array}{l}\text { Modification of forest: Enriched } \\
\text { natural forest with e.g., native } \\
\text { timber species. }\end{array}$} \\
\hline Surface area in ha: 4.7 & & & & & \\
\hline Percentage: $2 \%$ & & & & & \\
\hline $\begin{array}{l}\text { Plantation crop } \\
\text { combination-perennial cultivates * }\end{array}$ & \multirow{4}{*}{$\begin{array}{l}\text { Shade trees for intercropped } \\
\text { perennial plantation crops; } \\
\text { shade trees scattered } \\
\text { on parcel. }\end{array}$} & \multirow{4}{*}{$\begin{array}{l}\text { fruit, fodder, shade and timber } \\
\text { tree species. Plantation crops } \\
\text { like coffee, citrus fruits }\end{array}$} & \multirow{4}{*}{$\begin{array}{l}\text { In humid lowlands or tropical } \\
\text { humid/subhumid highlands } \\
\text { (depending on the plantation } \\
\text { crops concerned); usually in } \\
\text { smallholder subsistence system. }\end{array}$} & \multirow{4}{*}{$\begin{array}{l}\text { Phase 4: Cultivation of } \\
\text { domesticated tree crops in } \\
\text { intensively } \\
\text { managed plantations. }\end{array}$} & $\begin{array}{l}\text { Forest transformation: Plantations } \\
\text { of selected \& improved cultivars: }\end{array}$ \\
\hline Surface area in ha: 49.2 & & & & & \\
\hline \multirow{2}{*}{ Percentage: $6.8 \%$} & & & & & $\begin{array}{l}\text {-Smallholder coffee, } \\
\text { citrus plantations. }\end{array}$ \\
\hline & & & & & -(mixed) fruit orchards. \\
\hline $\begin{array}{l}\text { Plantation crop } \\
\text { combination-annual cultivates * }\end{array}$ & \multirow{3}{*}{$\begin{array}{l}\text { Trees intercropped with } \\
\text { predominate annual } \\
\text { agricultural crops. }\end{array}$} & \multirow{3}{*}{$\begin{array}{l}\text { timber species predominate, } \\
\text { fruit, fuelwood trees. some } \\
\text { woody plantation crops. }\end{array}$} & In humid lowlands or tropical & Phase 4: & $\begin{array}{l}\text { Scattered tree growing on } \\
\text { agricultural fields: }\end{array}$ \\
\hline Surface area in ha: 16.4 & & & humid/subhumid highlands & \multirow{2}{*}{$\begin{array}{l}\text { Cultivation of domesticated } \\
\text { tree crops and agricultural } \\
\text { cultivates in intensively } \\
\text { managed plantations/fields. }\end{array}$} & $\begin{array}{l}\text {-Individual Multipurpose fruit, } \\
\text { fodder, fuelwood and timber trees. }\end{array}$ \\
\hline Percentage: $20.6 \%$ & & & $\begin{array}{l}\text { Usually in smallholder } \\
\text { subsistence systems. }\end{array}$ & & $\begin{array}{l}\text {-Genetically modified trees on } \\
\text { cropland (e.g., oranges, timbers). }\end{array}$ \\
\hline \multicolumn{6}{|l|}{ Silvopastoral systems } \\
\hline $\begin{array}{l}\text { Trees crops on rangelands } \\
\text { or pastures }\end{array}$ & \multirow{3}{*}{$\begin{array}{l}\text { Trees scattered irregularly or } \\
\text { arranged according to some } \\
\text { systematic pattern with cattle } \\
\text { grazing in the understorey. }\end{array}$} & \multirow{3}{*}{ multipurpose trees } & \multirow{3}{*}{$\begin{array}{l}\text { In areas with less pressure on } \\
\text { plantation crop lands. }\end{array}$} & \multirow{3}{*}{$\begin{array}{l}\text { Phase 4: Cultivation of } \\
\text { domesticated tree crops in } \\
\text { intensively } \\
\text { managed plantations. }\end{array}$} & Scattered tree growing on pastures \\
\hline Surface area in ha: 142.7 & & & & & $\begin{array}{l}\text {-Individual Multipurpose fruit, } \\
\text { fodder, fuelwood and timber trees. }\end{array}$ \\
\hline Percentage: $59.6 \%$ & & & & & $\begin{array}{l}\text {-Genetically modified trees on } \\
\text { cropland (e.g., oranges, timbers). }\end{array}$ \\
\hline \multicolumn{6}{|l|}{ Agrosilvopastoral systems } \\
\hline Homegarden & \multirow{3}{*}{$\begin{array}{l}\text { Intimate, multi-storey } \\
\text { combination of various trees } \\
\text { and crops around } \\
\text { homesteads. }\end{array}$} & \multirow{3}{*}{$\begin{array}{l}\text { (exotic) fruit trees predominate, } \\
\text { (exotic) firewood, ornamental, } \\
\text { woody cultivates such as coffee, } \\
\text { lime, oranges. }\end{array}$} & \multirow{3}{*}{$\begin{array}{l}\text { In all ecological regions with } \\
\text { high density of } \\
\text { human population. }\end{array}$} & \multirow{3}{*}{$\begin{array}{l}\text { Phase 3: Cultivation of selective } \\
\text { native (and exotic) tree species } \\
\text { in artificially } \\
\text { established plantations. }\end{array}$} & $\begin{array}{l}\text { Forest transformation: } \\
\text { multi-storeyed tree } \\
\text { cropping systems. }\end{array}$ \\
\hline Surface area in ha: 11.2 & & & & & -Homegardens containing various \\
\hline Percentage: $4.7 \%$ & & & & & herbaceous (ornamental) plants. \\
\hline
\end{tabular}

* Both systems contain an integrated multi-storey of (mixed/dense) scattered trees in combination with plantation crops. However, a distinction is made between the domination of annual
(maize, beans, tomatoes, bananas) or perennial cultivates (coffee, cassava, lime, oranges) as the type of cultivate influences the density of the tree layer and the intensity of management. 


\subsection{Importance Value Plant Species}

We measured 550 woody plant individuals in the 30 transects, corresponding to 71 plant species, of which $63(89 \%)$ were native and $8(11 \%)$ were exotic. We found that Cedrela odorata had the highest IVIr $(8.7 \%)$, especially for its contribution in the basal area (Table 2). Due to its high basal area and relatively high frequency among transects, it was considered as the potentially most important arboreal species and appears to be planted frequently for timber in the agroforestry and silvopasture agroforestry systems. Coffea arabica had the second position in IVIs (6.4\%) as it is frequently intercropped in several agroforestry systems such as plantation crop combinations and home gardens. In the fallow/abandoned fragments, the native fruit tree species Pseudolmedia glabrata (6.3\%) was very abundant with a high density locally and basal area. The following ten species with the highest score account for $48 \%$ of the total IVIr and the remaining 61 species represent $52 \%$ of the total IVIr.

Table 2. The ten plant species with the highest index value (IVr) found at the ejido "Los Ídolos", Misantla. We present relative values which give the final importance value as well as the absolute data on relative plant density (Dr), frequency (Frr), and basal area (Bar).

\begin{tabular}{ccccc}
\hline Name & Dr & Frr & Bar & IVIr \\
\hline Cedrela odorata & 5.3 & 6.7 & 14.2 & 26.2 \\
Coffea arabica & 12.7 & 5.4 & 1.3 & 19.4 \\
Pseudolmedia glabrata & 7.5 & 2.2 & 9.2 & 18.9 \\
Ardisia compressa & 8.4 & 6.7 & 0.7 & 15.7 \\
Eupatorium quadrangulare & 8.0 & 2.7 & 1.3 & 12.0 \\
Thouinidium sp. & 1.3 & 1.3 & 8.8 & 11.4 \\
Inga vera & 3.1 & 4.9 & 3.4 & 11.4 \\
Oecopetalum mexicanum & 6.0 & 1.8 & 2.9 & 10.7 \\
Ficus aurea & 0.4 & 0.9 & 8.1 & 9.4 \\
Citrus sinensis & 1.8 & 3.6 & 2.0 & 7.4 \\
Other species (61) & 45.6 & 63.7 & 48.1 & 157.5 \\
\hline Total & 100 & 100 & 100 & 300 \\
\hline
\end{tabular}

\subsection{Agroforestry Systems Management}

\subsubsection{Forest Garden (FG)}

Were identified 40 species in the FG, all native to the region. The most important species here was P. glabrata with $13 \%$ of the total IVIr with food production as its main use. Eupatorium quadrangulare with $9.5 \%$ is mostly used for firewood collection. Thouinidium sp. had an IVIr of $8 \%$ and the timber of this tree is generally used as a construction material. Ficus aurea with $6.4 \%$ of total the IVIr is often left standing after a clearing to serve as shade trees for cattle. The remaining 30 species had a low proportion ( $36 \%$ of the total IVIr).

\subsubsection{Home Garden (HG)}

We recorded 32 species, 27 (84\%) were native and five (16\%) were exotic species. Important species in this agroforestry system were Ardisia compressa (with an IVIr of 10\%) as it is mainly used for food production. C. arabica with an IVIr of $8 \%$ is mostly used for beverage consumption and income generation. C. odorata also had an IVIr of 7.6 and the high-quality timbers of this tree are generally used for the construction of furniture and artisanal crafts. Citrus sinensis (orange) had an IVIr of 21 and is planted mainly for personal consumption since its market value has declined over the past decades [21]. The following 23 species had a low proportion ( $35.7 \%$ of the total IVIr). Finally, three species contributed to the remaining $6 \%$ of the IVIr. 


\subsubsection{Plantation Crop Combination Annual Cultivates (AC)}

Thirteen species were identified as AC consisting of nine native species $(69 \%)$ and four exotic species (31\%). Species with a high IVIr were C. odorata with $38 \%$ of total IVIr, and C. arabica with a contribution of $14 \%$. Inga vera had an IVIr of $10.2 \%$ and is generally used as shade trees for growing coffee, with personal consumption and firewood collection as additional uses. Persea schiedeana had an IVIr of $8 \%$ and is used for personal consumption (fruit) and as a construction material or firewood. The importance value of the first ten common species was $94 \%$, which indicates a low complexity and variety of ligneous plant species composition in this agroforestry system.

\subsubsection{Plantation Crop Combination Perennial Cultivates (PC)}

The plantation crop combination perennial cultivates (PCCPC) included 18 species that were identified, with a total number of 14 native species (78\%) and four exotic species $(22 \%)$. The important species components in this agroforestry system and their main use was C. arabica with an IVIr of $19 \%$, which was the main perennial cultivate in this system. Oecopetalum mexicanum with an IVIr of $15.3 \%$ is an important food tree and provides additional income by selling the fruits of the tree. Heliocarpus appendiculatus had an IVIr of $9.6 \%$ and is generally used as a construction material for houses. I. vera had an IVIr of $8 \%$ and is regularly planted to optimize the growth conditions for C. arabica. The importance value of the first ten common species was $87 \%$. The remaining $13 \%$ corresponded to eight species with low percentage contributions.

\subsubsection{Trees on Pastures (TP)}

The TP system had 20 species in total, which were identified in this system where $18(90 \%)$ species were found to be native and two $(10 \%)$ exotic. The important species components in this agroforestry system and their main use were: $C$. odorata with an IVIr of $22 \%$ as a perennial cultivate in this system; Pouteria sapota, which had an IVIr of $11 \%$, its fruits are used for personal consumption or sold for cash income; Ocotea sp., with an IVIr of $7.6 \%$ and is a timber source for the construction of sheds and houses; and Psidium guajava, which had an IVIr of $5.6 \%$ and is used as shade trees for cattle, firewood, and fruit collection. The importance value of the ten most common species was $74 \%$, even the remaining $26 \%$ was represented by ten more species, which indicates that-despite a low tree density - a relatively high variety of ligneous plant species was being planted or left over after exploitation of former forests in this agroforestry system.

\subsection{Social Use Value (SUV) in Terms of Ecosystem Goods and Services from Local Land Management}

We showed the assigned cultural value for identity; commercial and subsistence of the present agroforestry systems in the ejido "Los Ídolos". The mean perceived value is relevant to show the general importance of an agroforestry system, and the perceived values of every agroforestry system are explained below (Table 3).

The crop combination systems (PC, AC) in the ejido are always constituted by one or several (see above) of the three-local management: coffee plantations, cachichinales and citrus plantations (Table 3).

The cultural values ranged between 3.5 and 8.8 (Table 3) wherein the milpa received the highest (8.6 for subsistence) and acahuales-secondary forest-(inside the FG) had the lowest value in terms of commercial value. In this sense, the agroforestry system was perceived to be the highest in TP systems with a 7.8 (Trees on pastures) and the lowest in the FG having a 3.5. The perceived subsistence values of the agroforestry systems were highly variable, AC systems that received an 8.6 were the highest, while TP systems received a 4.9. Table 3 reveals that each system was perceived to be important for one, sometimes two specific purposes: cultural identity, commercial or subsistence; however, there is no system that can cope with all the needs of a farmer. On average the AC and the PC (cachichinal), both with a 7.3, are perceived to be the most important for the farmers. 
Table 3. Assigned value of ecosystem goods: cultural, commercial, and subsistence mean value of the present land management systems in the ejido "Los Ídolos", Misantla, Central Veracruz, Mexico.

\begin{tabular}{cccccc}
\hline $\begin{array}{c}\text { Local } \\
\text { Management }\end{array}$ & Agroforestry System & $\begin{array}{c}\text { Cultural } \\
\text { Identity Value }\end{array}$ & $\begin{array}{c}\text { Commercial } \\
\text { Value }\end{array}$ & $\begin{array}{c}\text { Subsistence } \\
\text { Value }\end{array}$ & Mean \\
\hline Acahual & Forest garden(FG) & 6.8 & 3.5 & 5.8 & 5.4 \\
\hline Cafetal & $\begin{array}{c}\text { Plantation crop combination- } \\
\text { perennial cultivates (PC) }\end{array}$ & 7.8 & 5.5 & 7.5 & 6.9 \\
\hline Cachichínal & $\begin{array}{c}\text { Plantation crop combination- } \\
\text { perennial cultivates (PC) }\end{array}$ & 7.8 & 7.7 & 6.5 & 7.3 \\
\hline Cítrico & $\begin{array}{c}\text { Plantation crop combination- } \\
\text { perennial cultivates (PC) }\end{array}$ & 7.6 & 6.3 & 6.8 & 6.9 \\
\hline Huerto familiar & Home garden (HG) & 8.3 & 4.0 & 8.1 & 6.8 \\
\hline Milpa & $\begin{array}{c}\text { Plantation crop combination- } \\
\text { annual cultivates (AC) }\end{array}$ & 8.8 & 4.4 & 8.6 & 7.3 \\
\hline Potrero con árboles & Trees on pastures (TP) & 7.9 & 7.8 & 4.9 & 6.9 \\
\hline
\end{tabular}

Forest gardens (FG): six of the eight provisioning services are used in the FG. However, with an SUV of $4 \%$, FG had the lowest subsistence proportion of all systems. A few farmers extracted medicinal woody plant species (5), construction wood (4), or artisanal products (4) from the FG. The farmers use a total of 12 species from the FG (Table 4 ).

Table 4. Provision services associated within land management systems: Forest gardens (FG), Home gardens (HG), Annual Cultivates (AC), Plant Crop (PC) and Trees on Pasture systems (TP) in Los Ídolos, Misantla, Central Veracruz, Mexico.

\begin{tabular}{|c|c|c|c|c|c|c|c|c|}
\hline \multirow[b]{2}{*}{ Use Category } & \multicolumn{2}{|c|}{ FG } & \multicolumn{2}{|c|}{ HG } & \multicolumn{2}{|c|}{ PC } & \multicolumn{2}{|c|}{ TP } \\
\hline & $\mathrm{Sp} \%$ & $\begin{array}{l}\text { Species } \\
\text { Used (\#) }\end{array}$ & $\mathrm{Sp} \%$ & $\begin{array}{l}\text { Species } \\
\text { Used (\#) }\end{array}$ & Sp \% & $\begin{array}{l}\text { Species } \\
\text { Used (\#) }\end{array}$ & Sp \% & $\begin{array}{l}\text { Species } \\
\text { Used (\#) }\end{array}$ \\
\hline Crafting & 0.8 & 4 & 6.1 & 13 & 5.7 & 11 & 2.8 & 7 \\
\hline Food & 0.6 & 2 & & & 10 & 14 & 4.5 & 11 \\
\hline Medicinal & 1 & 4 & 3.7 & 12 & 2.6 & 7 & 3.3 & 7 \\
\hline Construction & 1.2 & 5 & 0.4 & 2 & 6.9 & 14 & 4.9 & 13 \\
\hline Shadow and fencing trees & & & 0.4 & 2 & & & 8.7 & 22 \\
\hline Fodder & 0.2 & 1 & & & & & 1.8 & 4 \\
\hline Firewood & 0.2 & 1 & 0.4 & 2 & 6.9 & 14 & 7.1 & 18 \\
\hline Ornamental & & & & & & & 1.4 & 7 \\
\hline Reforestation & & & & & 5.5 & 18 & 4.5 & 14 \\
\hline Total & 4 & 12 & 19 & 58 & 38 & 30 & 39 & 46 \\
\hline
\end{tabular}

Home gardens (HG): farmers use 58 species from the HG, the highest number of differently used species belonging to six provisional services. The subsistence value was mainly determined by the high number of species used for ornamental (27), food (13), and medicinal (12) woody species. Benefits of both medicinal and ornamental plants are socially perceived to be the most abundant in HG (Table 4).

Annual Cultivates (AC): this type of agroforestry system was not perceived to be important in terms of provisioning services. The farmers explained that AC had high subsistence value; however, had a low SUV woody plants. The trees and shrubs resources which remain in these agricultural fields are occasionally collected and consumed spontaneously, rather than on a regular basis (Table 4).

Plant Crop (PC): The interviewed farmers were frequently benefited by the provided goods and services of PC systems. This explained its high SUV\% rate of 38\%, based on the preferred extraction of a diverse range of food products (14), construction wood (14), firewood (14), and artisanal products (11). The farmers preferred to promote 18 different species for reforestation purposes planted in PCCPC systems, which underlined its perceived importance within the ejido. We registered 30 useful species in the PC (Table 4). 
Trees on Pasture systems (TP): This system received an SUV of 39\% as every provisional ecosystem service is occasionally of beneficial use for most of the interviewed farmers. Especially the provision of shade (22), firewood (18), and construction wood (13) species are generally used in TP. Furthermore, artisanal, food, fodder, and medicinal goods were occasionally collected (Table 4).

\subsection{Most Valuable Woody Species in Forest Management}

Based on the high numbers of use types and frequency of use, P. schiedeana and C. sinensis both of which had an RI of 1.03, were popular due to their multifunctional characters (Table 5). Their trees provide high-quality timber for construction, fruits, medicinal use, and firewood, and are planted also for its shade function and ornamental value [34,35]. O. mexicanum scored an RI of 0.88 due to the locally high commercial value of the fruits, so is also considered as a beneficial cash crop. Besides its commercial importance, it is used as construction material, firewood, medicinal products, and ornamental trees. Furthermore, eight species shared an RI value of 0.73 since they occupied all five use types, although their main use is placed between brackets: Bursera simaruba (fences), Diphysa robinioides (firewood), Gliricidia sepium (fences, host plant of Vanilla planifolia), C. odorata (commercial timber), P. guajava (fruits), Citrus reticulata (medicinal), Salix humboltiana (firewood), and P. Sapota (fruits) (Table 5).

Table 5. The 11 most valuable agroforestry tree and shrub species in the study area according to the interviewed farmers in the ejido "Los Ídolos". Relative Importance Index (RI); number of use categories of a species divided by the total number of use categories of the most useful species (NUC); and the number of use types attributed to a species divided by the total number of use types of the most useful species (NT).

\begin{tabular}{cccc}
\hline Species & NUC & NT & RI \\
\hline Persea schiedeana & 0.027 & 1.00 & 1.03 \\
Citrus sinensis & 0.027 & 1.00 & 1.03 \\
Oecopetalum mexicanum & 0.023 & 0.86 & 0.88 \\
Bursera simaruba & 0.020 & 0.71 & 0.73 \\
Diphysa robinioides & 0.020 & 0.71 & 0.73 \\
Gliricidia sepium & 0.020 & 0.71 & 0.73 \\
Cedrela odorata & 0.020 & 0.71 & 0.73 \\
Psidium guajava & 0.020 & 0.71 & 0.73 \\
Citrus reticulata & 0.020 & 0.71 & 0.73 \\
Salix humboldtiana & 0.020 & 0.71 & 0.73 \\
Pouteria sapota & 0.020 & 0.71 & 0.73 \\
\hline
\end{tabular}

\section{Discussion}

The smallest proportion in the ejido was FG with five ha and covered $2 \%$ of the study area. However, the transect data showed that FG had the highest floristic diversity of all the studied systems and formed a habitat for at least 40 different species, which coincides with the findings of Lascurain et al. [36] and López-Acosta et al. [37]. These authors identified (municipalities of Misantla, Tenochtitlan, Yecuatla, Mexico) 52 species in ten transects covering $1000 \mathrm{~m}^{2}$ in the same region. Interview data indicated that this agroforestry system was the least recognized as potentially useful by the interviewed farmers. The cultural identity, commercial, and subsistence value received $6.8,3.5$, and 5.8, respectively, giving a mean value of 5.4, which might also explain its relatively low area coverage. This low perceived importance of the FG was confirmed by the low use intensity corresponding to a total SUV of 3.9\%. Regarding native plant use and protection, the system was very important as all species found and used are native.

HG systems are situated around the homesteads of farmers and at 11 ha, this system accounted for $4.7 \%$ of the study area. HG systems had the second highest diversity with 32 identified ligneous plant species, and was also important for the cultural identity of farmers and scored an average of 
8.3. Regarding the small size of the HG and a high number of species, the system is important for its subsistence value (8.1), but less so with respect to its commercial value (4.0). The SUV of the HG was $19 \%$, with 58 species mainly used for food, medicinal products, and ornamental services. The number of used species in HG was nearly the same as those measured in area with similar climate conditions corresponding to La Sierra de Misantla: Alvarez-Buylla et al. [38] identified 62 species in HG systems of Balzapote, Los Tuxtlas, Veracruz. In addition, Van der Wal and Bongers [39] observed 195 species that might be explained due to a larger sample size (61 home gardens of several sizes) in the state of Tabasco, México with similar species, despite a slightly warmer climate.

AC systems comprised an area of 16 ha $(6.8 \%)$ with 13 species, the lowest floristic diversity in "Los Idolos". The woody plant species were less abundant when compared to the other agroforestry systems, which was confirmed by a low measured SUV: none of the interviewed farmers visited the AC for the systematical collection of woody plant products. Even though farmers indicated little interest in cultivating and using trees species in the AC, the agroforestry system scored a high cultural identity value (8.8) and subsistence value (8.6) as these agroforestry systems also provide crops that are eaten daily by both livestock and the inhabitants of the community.

With regard to economic value, the AC scored a 4.4 as staple crops have a low market value. The difference in the extent of extracted exotic and native woody plants could not be measured as the farmers did not use the system for woody plant products. Records from the transect data showed that a third $(75 \%)$ of the plants were native and $25 \%$ were exotic.

PC systems had a size of 49 ha, representing $20.6 \%$ of the ejido corresponding to different local examples such as cachichinales, coffee, and citrus plantations. Although they had a relatively large land coverage, they had a lower floristic diversity (18 species) than HG and FG; however, it was relatively similar to that observed by López-Acosta et al. [37] who identified 28 species in coffee plantations and 26 in the cachichinales. The low diversity was explained by the fact that most PC systems were dominated by introduced perennial commercial trees-shrubs such as C. arabica, Citrus aurantifolia, C. sinensis, and native ones like O. mexicanum. Different local examples of PC systems (cachichinales, coffee, and citrus plantations) generally scored a high cultural identity value of 7.7 on average. Despite these plantations being partly commercially oriented, the perceived commercial value of 6.5 was rather low as a result of the low market prices for coffee and citrus [40]. However, the mean subsistence value was 6.9 , which was not that high since harvests of collected goods were sold and self-consumption. Taking the mean of the tree measured values, the PCCPC systems scored on average 7.0 for their provided cultural, commercial, and subsistence values. Furthermore, the SUV value of the PCCPC systems accounted for $38 \%$ of the 30 used woody plants, which underlined the importance of these systems for securing local subsistence needs. This outcome suggests that more local species were perceived to be useful than that indicated by López-Acosta et al. [37], who identified 19 useful species in the PCCPC systems (coffee plantations and cachichinales).

TP was the most widespread of all identified agroforestry system in the ejido "Los Ídolos". This system covered 143 ha and represented $60 \%$ of the total surface. The TP had the lowest tree density of all systems and only 20 species with 34 individuals were identified. The cultural and commercial value of TP systems was high with values of 7.9 and 7.8 , respectively. The subsistence value was 4.9 , lower than the other systems, which may be explained by the low tree density in pasture fields. TP systems were simultaneously promoted by farmers for the extraction of tree products. In contrast, with an SUV value of $39 \%$, several tree products from 46 species were used within the TP systems. This makes the TP species the second most utilized after HG. Additionally, as PCCPC systems, TP had relatively high support to be promoted as a key land use system within the ejido, since several farmers had indicated that they would plant 14 different woody species on TP systems where tree cover is scarce. However, despite low tree densities, the importance values of trees measured in this system were dominated by ul native species ( $85 \%$ of the IVIr).

Due to their multi-functionality, 11 species were determined as the most useful by the interviewed farmers with an RI ranging between 0.73 and 1.03. Six of these 11 species were highlighted for 
promotion as a key species for reforestation in TP systems with scarce tree cover: P. schiedeana, which is important for auto consumption and as construction material [41], and C. sinensis due to its function as an edible product, firewood, and medicinal use. O. mexicanum is locally abundant; however worldwide, it is a threatened species which serves—besides its relative high commercial value [36] —as an important product for auto consumption, construction material, and firewood. Another tree species which can bridge financial gaps in rural families is C. odorata, a precious timber species [42], whose wood is also locally used for artisanal furniture, construction material, and medicinal purposes. P. sapota produces fruits (mamey), medicinal seeds and leaves; and solid timber for local constructions [35]. The branches of S. humboldtania can be pruned and are thus well suited as firewood and construction material, while the leaves have medicinal uses. These six-key species, together with 16 other species, can be used to design suitable PC and TP systems.

PC and TP systems are preferred by the farmers to be promoted within the ejido "Los Ídolos" to secure subsistence needs. However, it is necessary to encourage products with commercial potential to maintain the cultural identity of the ejidatarios and conserve biodiversity and genetic diversity in La Sierra de Misantla [28,33,43].

\section{Conclusions}

This study revealed that the diversity in an agroforestry system corresponded well with the diversity of needed goods for specific cultural, ecological, economic, and subsistence purposes.

To achieve a better land use planning, the landowners in "Los Ídolos" should has a potential trade-off: (i) the farmers choose agroforestry systems such as the IF, HG and CPC to fulfil subsistence security or (ii) they prefer a more economic-oriented destination of the land by choosing a TP system, which generates more financial outcomes through selling timber and allows for keeping livestock, despite the lower abundance of useful woody plants. This depends on the primary needs of each owner and aligned with the collective needs of the ejido.

Pasture lands for cattle ranching are evidently the most popular among the interviewed farmers and cover the largest area due to a growing market for cattle-derived products such as meat [21]. Still, this study clearly indicated that the maintenance of high (native) species diversity (managed in diverse agroforestry systems) served as an important safety net. This is especially so when the production of (exotic) cash crops suffer low market prices or are influenced by political choices where the importance of locally sustaining traditionally managed agroforestry systems should be underlined [44].

Acknowledgments: Gregoria Zamora for help in formatting and editing the manuscript. We thank Iliana Romero and Emanuel Pantoja for their invaluable help in the field jobs, and Don Juan Carrera for his support and social contact with the ejido.

Author Contributions: Sjoerd Pieterse, Lascurain-Rangel, Jorge Gómez-Díaz, and Juan López-Acosta wrote and revised the manuscript, Sjoerd Pieterse and Juan López-Acosta organized and performed the data analyses, field jobs, and interpreted data.

Conflicts of Interest: The authors declare no conflict of interest. 


\section{Appendix Appendix}

Table A1. Family, Species, management systems presence, uses (A = Artisanal), $(\mathrm{B}=$ Edible $),(\mathrm{C}=$ Construction $),(\mathrm{D}=$ Fences $/$ Shadow $),(\mathrm{E}=\mathrm{Fodder}),(\mathrm{F}=$ Firewood $)$, ( $\mathrm{G}=$ Medicine), $(\mathrm{H}=$ Ornamental), ( $\mathrm{I}=$ Reforestation) and origin of all species recorded in this study.

\begin{tabular}{|c|c|c|c|c|c|c|c|c|}
\hline Family & Species & FG & HG & PCCAC & РССРC & $\mathbf{T P}$ & Uses & Exotic \\
\hline Adoxaceae & Sambucus nigra (L.) & & $x$ & & & & G & $\mathrm{x}$ \\
\hline Anacardiaceae & Astronium gravolens (Jacq.) & $\mathrm{x}$ & & & & $\mathrm{x}$ & A, D & \\
\hline Anacardiaceae & Mangifera indica (L.) & & $\mathrm{x}$ & & $x$ & $x$ & $\mathrm{~B}, \mathrm{C}, \mathrm{D}, \mathrm{F}$ & $\mathrm{x}$ \\
\hline Anardiaceae & Spondias mombin (L.) & & & & & $x$ & $\mathrm{D}$ & \\
\hline Anardiaceae & Spondias purpurea (L.) & & & & & $\mathrm{x}$ & $\mathrm{D}$ & \\
\hline Annonaceae & Annona glabra (L.) & $\mathrm{x}$ & $\mathrm{x}$ & & $\mathrm{x}$ & & $\mathrm{B}, \mathrm{G}$ & \\
\hline Annonaceae & Annona muricata (L.) & & $\mathrm{x}$ & & $\mathrm{x}$ & & $\mathrm{B}, \mathrm{G}, \mathrm{H}$ & \\
\hline Apocynaceae & Tabernaemontana alba (Mill.) & & $\mathrm{x}$ & & & $x$ & $\mathrm{H}$ & \\
\hline Apocynaceae & Stemmadenia littoralis (Juss.) & $\mathrm{x}$ & & & & & $\mathrm{B}, \mathrm{D}, \mathrm{F}$ & \\
\hline Araliaceae & Dendropanax arboreus (L.) Decne. \& Planch. & $\mathrm{x}$ & $\mathrm{x}$ & & & $\mathrm{x}$ & $\mathrm{D}, \mathrm{E}, \mathrm{H}$ & \\
\hline Araliaceae & Schefflera actinophylla (Endl.) Harms & & $\mathrm{x}$ & & & & $\mathrm{H}$ & $\mathrm{x}$ \\
\hline Arecaceae & Phoenix roebelenii (O’Brien.) & & $\mathrm{x}$ & & & & $\mathrm{H}$ & $\mathrm{x}$ \\
\hline Asparagaceae & Yucca sp. (L.) & & $x$ & & & & $\mathrm{~B}, \mathrm{D}$ & \\
\hline Asteraceae & Eupatorium quadrangulare (DC.) & $\mathrm{x}$ & & & & & & \\
\hline Ateraceace & Verbisina sp. (L.) & & $x$ & & & & G & \\
\hline Bignoniaceae & Jacaranda mimosifolia (D.Don.) & & $\mathrm{x}$ & & & & $\mathrm{H}$ & $\mathrm{x}$ \\
\hline Bignoniaceae & Tabebuia rosea (Bertol.) DC. & & $\mathrm{x}$ & & & & $\mathrm{H}$ & \\
\hline Boraginaceae & Wigandia urens (Ruiz \& Pav.) Kunth & & $x$ & $x$ & $x$ & $\mathrm{x}$ & $\mathrm{C}, \mathrm{D}, \mathrm{F}, \mathrm{I}$ & \\
\hline Burseraceae & Bursera simaruba (L.) Sarg. & $\mathrm{x}$ & $\mathrm{x}$ & $\mathrm{x}$ & & $x$ & $\mathrm{D}, \mathrm{E}, \mathrm{F}, \mathrm{G}, \mathrm{H}$ & \\
\hline Calophyllaceae & Mammea americana (L.) & & & & $x$ & $x$ & $\mathrm{~B}, \mathrm{G}, \mathrm{I}$ & $\mathrm{x}$ \\
\hline Cannabaceae & Trema micrantha (L.) Blume & $x$ & $x$ & & & $x$ & $\mathrm{C}, \mathrm{F}$ & \\
\hline Caricaceae & Carica papaya (L.) & & $\mathrm{x}$ & & $\mathrm{x}$ & & B & \\
\hline Caricaceae & Carica sect. Vasconcella (A. St.-Hil.) & & & & $\mathrm{x}$ & & B & \\
\hline Casuarinaceae & Casuarina cunninghamiana (Miq.) & & $\mathrm{x}$ & & & & $\mathrm{H}$ & $\mathrm{x}$ \\
\hline Combretaceae & Terminalia catappa (L.) & & $x$ & & & $x$ & $\mathrm{H}, \mathrm{I}$ & $x$ \\
\hline Cyatheaceae & Cyathea divergens (Kunze.) & & $\mathrm{x}$ & & & & $\mathrm{H}$ & \\
\hline Ebenaceae & Diospyros digyna (Jacq.) & $\mathrm{x}$ & & & $x$ & $x$ & $\mathrm{~B}, \mathrm{G}, \mathrm{I}$ & \\
\hline Euphorbiaceae & Croton draco (Schltdl. \& Cham.) & $x$ & & & $x$ & $\mathrm{x}$ & $\mathrm{D}, \mathrm{F}, \mathrm{G}$ & \\
\hline Euphorbiaceae & Jatropha curcas (L.) & & $\mathrm{x}$ & & $\mathrm{x}$ & & B, I & \\
\hline Euphorbiaceae & Sapium lateriflorum (Hemsl.) & $x$ & $\mathrm{x}$ & & $x$ & $x$ & $\mathrm{D}, \mathrm{F}, \mathrm{H}, \mathrm{I}$ & \\
\hline
\end{tabular}


Table A1. Cont.

\begin{tabular}{|c|c|c|c|c|c|c|c|c|}
\hline Family & Species & FG & HG & PCCAC & РССРС & TP & Uses & Exotic \\
\hline Euphorbiaceae & Alchornea latifolia (Sw.) & $\mathrm{x}$ & & & & & $\mathrm{C}, \mathrm{F}$ & \\
\hline Euphorbiaceae & Sapium nitidum (Monach.) Lundell & $x$ & & & & & $\mathrm{C}, \mathrm{F}$ & \\
\hline Euphorbiaceae & Manihot esculenta (Crantz.) & & $x$ & $x$ & & & B & \\
\hline Fabaceae & sp. 1 & & $x$ & $x$ & & & & \\
\hline Fabaceae & Cojoba arborea (L.) Britton \& Rose & $x$ & $x$ & & $x$ & & $\mathrm{C}, \mathrm{H}$ & \\
\hline Fabaceae & Delonix regia (Bojer ex Hook.) Raf. & & $x$ & & & & $\mathrm{H}$ & $x$ \\
\hline Fabaceae & Diphysa robinioides (Benth.) & & $x$ & & $x$ & $x$ & $\mathrm{~A}, \mathrm{C}, \mathrm{D}, \mathrm{F}, \mathrm{H}$ & \\
\hline Fabaceae & Erytrina folkersii (Krukoff.) & & $x$ & & & & $\mathrm{D}, \mathrm{H}$ & \\
\hline Fabaceae & Gliricidia sepium (Kunth ex Steud.) & & $x$ & & $x$ & $x$ & $\mathrm{D}, \mathrm{E}, \mathrm{F}, \mathrm{G}, \mathrm{H}$ & \\
\hline Fabaceae & Inga alata (Benoist.) & & & & $x$ & $x$ & $\mathrm{C}, \mathrm{F}$ & \\
\hline Fabaceae & Inga jinicuil (Schltdl. \& Cham.) & $x$ & $\mathrm{x}$ & & $x$ & $x$ & $\mathrm{~B}, \mathrm{D}, \mathrm{H}, \mathrm{I}$ & \\
\hline Fabaceae & Inga vera (Willd.) & $x$ & $x$ & $x$ & $x$ & $x$ & $\mathrm{D}, \mathrm{F}, \mathrm{H}, \mathrm{I}$ & \\
\hline Fabaceae & Leucaena leocucephala (Lam.) de Wit & & & & & $x$ & $\mathrm{C}, \mathrm{F}$ & \\
\hline Gesneriaceae & Miconia argentea (Lapeyr.) & $\mathrm{x}$ & & & & & & \\
\hline Icacinaceae & Oecopetalum mexicanum Greenm. \& CH. Thomps & & $x$ & $x$ & $\mathrm{x}$ & $x$ & $\mathrm{~B}, \mathrm{D}, \mathrm{F}, \mathrm{G}, \mathrm{H}, \mathrm{I}$ & \\
\hline Icacinaceae & Calatola costarisensis (Standl.) & $\mathrm{x}$ & & & & & & \\
\hline Lauraceae & Nectranda sp. & $x$ & & & $x$ & $x$ & $\mathrm{~A}, \mathrm{C}, \mathrm{I}$ & \\
\hline Lauraceae & Ocotea sp. (Aubl.) & & $\mathrm{x}$ & & $x$ & $x$ & A & \\
\hline Lauraceae & Persea Americana (Mill.) & & $x$ & & $x$ & $x$ & $B, C, D, G$ & \\
\hline Lauraceae & Persea schiedeana (Mill.) & $\mathrm{x}$ & $x$ & $\mathrm{x}$ & $x$ & $x$ & $\mathrm{~A}, \mathrm{~B}, \mathrm{C}, \mathrm{D}, \mathrm{F}, \mathrm{H}, \mathrm{I}$ & \\
\hline Lauraceae & Phoebe paniculata (Nees.) & $x$ & & & & & $\mathrm{~A}, \mathrm{C}, \mathrm{F}$ & \\
\hline Lauraceae & Beilschmiedia anay (S.F Blake) & & $x$ & & $x$ & $x$ & $\mathrm{~B}, \mathrm{C}, \mathrm{F}, \mathrm{I}$ & \\
\hline Lauraceae & Licaria triandra (Sw.) Kosterm. & $\mathrm{x}$ & & & & & $\mathrm{C}, \mathrm{F}$ & \\
\hline Leguminoceae & Lysiloma acupulensis (Kunth.) Benth. & & & & $x$ & $x$ & C, D & \\
\hline Lythraceae & Lagerstroemia indica (L.) & & $x$ & & & & $\mathrm{H}$ & $x$ \\
\hline Malpighiaceae & Byrsonima crasiffolia (L.) Kunth & $x$ & $x$ & & & & $\mathrm{~B}$ & \\
\hline Malpighiaceae & Bunchosia sp. (Kunth.) & $x$ & & & & & & \\
\hline Malvaceae & Guazuma ulmifolia (Lam.) & & & & & $x$ & $\mathrm{D}, \mathrm{F}, \mathrm{I}$ & \\
\hline Malvaceae & Heliocarpus appendiculatus (Turcz.) & $x$ & $x$ & & $x$ & $x$ & $\mathrm{~A}, \mathrm{E}$ & \\
\hline Malvaceae & Pseudobombax ellipticum (Kunth) Dugand & & & & & & $\mathrm{D}$ & \\
\hline Malvaceae & Bernoullia flammea (Oliv.) & $x$ & & & & & $\mathrm{~F}$ & \\
\hline Malvaceae & Hampea nutricia (Fryxell.) & $x$ & & & & & & \\
\hline Malvaceae & Hibiscus sp. (L.) & & $x$ & & & & $\mathrm{~F}, \mathrm{G}$ & \\
\hline
\end{tabular}


Table A1. Cont.

\begin{tabular}{|c|c|c|c|c|c|c|c|c|c|}
\hline Family & Species & FG & HG & PCCAC & РССРС & TP & Uses & \multicolumn{2}{|c|}{ Exotic } \\
\hline Melastomataceae & Conostegia xalapensis (Bonpl.) D. Don & $x$ & & & & $x$ & $\mathrm{~B}, \mathrm{~F}$ & & \\
\hline Meliaceae & Azadirachta indica (A.Juss) & & $x$ & & & & G & $\mathrm{x}$ & \\
\hline Meliaceae & Cedrela odorata (L.) & $x$ & $x$ & $x$ & $\mathrm{x}$ & $x$ & A, C, F, G, I & & \\
\hline Meliaceae & Guarea glabra (Vahl.) & $x$ & & & $\mathrm{x}$ & $\mathrm{x}$ & $\mathrm{C}, \mathrm{F}$ & & \\
\hline Meliaceae & Melia azedarach (L.) & & $\mathrm{x}$ & & $\mathrm{x}$ & $x$ & $C, D, F, H$ & $x$ & \\
\hline Meliaceae & Swietenia macrophylla (King.) & $x$ & & & $\mathrm{x}$ & $x$ & A, C, I & & \\
\hline Meliaceae & Guarea sp. (F. Allam.) ex L. & $x$ & & & & & $\mathrm{C}, \mathrm{F}$ & & \\
\hline Meliaceae & Trichilia sp. (P. Browne) & & $\mathrm{x}$ & & & & $\mathrm{D}$ & & \\
\hline Moraceae & Brosimum alicastrum (Sw.) & & & & & $\mathrm{x}$ & $\mathrm{A}, \mathrm{E}$ & & \\
\hline Moraceae & Ficus sp. (L.) & & $x$ & & & & $\mathrm{H}$ & & \\
\hline Moraceae & Pseudolmedia glabrata (C.C. Berg.) & $x$ & $\mathrm{x}$ & & $\mathrm{x}$ & $x$ & $\mathrm{~B}, \mathrm{H}, \mathrm{I}$ & & \\
\hline Moraceae & Pseudolmedia oxyphyllaria (Donn. Sm.) & $x$ & & & & $x$ & C, D, F & & \\
\hline Moraceae & Ficus aurea (Nutt.) & $x$ & & & & & $\mathrm{~F}, \mathrm{H}, \mathrm{I}$ & & \\
\hline Moraceae & Trophis racemosa (L.) Urb. & $x$ & & & & & $\mathrm{~B}, \mathrm{~F}$ & & \\
\hline Moraceae & Castilla elastica (Sessé.) ex Cerv. & & $\mathrm{x}$ & & & & $\mathrm{C}, \mathrm{F}$ & & \\
\hline Myrsinoideae & Ardisia compressa (Kunth.) & $x$ & $x$ & $\mathrm{x}$ & $\mathrm{x}$ & $x$ & $\mathrm{~B}, \mathrm{~F}$ & & \\
\hline Myrtaceae & Eugenia malaccensis (L.) & & & & & $x$ & $\mathrm{~F}$ & & \\
\hline Myrtaceae & Pimenta dioica (L.) Merr. & & $\mathrm{x}$ & & $\mathrm{x}$ & $x$ & $\mathrm{~B}, \mathrm{D}, \mathrm{F}, \mathrm{I}$ & & \\
\hline Myrtaceae & Psidium guajava (L.) & & & & $x$ & $x$ & $A, B, D, F, G$ & & \\
\hline Nyctaginaceae & Bougainvillea spectabilis (Willd.) & & $x$ & & & & $\mathrm{H}$ & $x$ & \\
\hline Nyctaginaceae & Pisonia aculeata (L.) & $x$ & $x$ & & & & $\mathrm{~F}$ & $x$ & \\
\hline Papaveraceae & Bocconia frutescens (L.) & & $\mathrm{x}$ & & $x$ & & G & & \\
\hline Pinaceae & Pinus sp. (L.) & & $x$ & & & $x$ & $\mathrm{H}$ & $x$ & \\
\hline Piperaceae & Piper amalago (L.) & $x$ & $\mathrm{x}$ & & & $\mathrm{x}$ & $\mathrm{B}$ & & \\
\hline Piperaceae & Piper schiedeanum (Schltdl.) & $x$ & & & & & $\mathrm{~F}$ & & \\
\hline Platanaceae & Platanus mexicana (Moric.) & & & & & $x$ & $\mathrm{~A}, \mathrm{C}, \mathrm{F}, \mathrm{H}$ & & \\
\hline Poaceae & Guadua aculeata (Rupr. ex E. Fourn.) & & $x$ & & $x$ & $\mathrm{x}$ & $\mathrm{A}, \mathrm{C}, \mathrm{D}, \mathrm{H}$ & & \\
\hline Rosaceae & Prunus persica (L.) Batsch & & $\mathrm{x}$ & & & & $\mathrm{B}, \mathrm{G}, \mathrm{H}$ & 3 & $x$ \\
\hline Rubiaceae & Coffea arabica (L.) & & $x$ & $\mathrm{x}$ & $\mathrm{x}$ & & $A, B, D, F$ & 4 & $x$ \\
\hline Rubiaceae & Morinda citrifolia (L.) & & $x$ & & & & $\mathrm{G}$ & 1 & \\
\hline Rubiaceae & Psychotria sp. (L.) & $x$ & & & & & $\mathrm{~F}$ & 1 & $x$ \\
\hline Rutaceae & Casimiroa edulis (La Llave \& Lex.) & $x$ & & & & $x$ & $B, G$ & 2 & \\
\hline Rutaceae & Citrus aurantifolia (Juss.) & & $x$ & & $x$ & $x$ & $\mathrm{~B}, \mathrm{G}, \mathrm{I}$ & 3 & $x$ \\
\hline
\end{tabular}


Table A1. Cont.

\begin{tabular}{|c|c|c|c|c|c|c|c|c|c|}
\hline Family & Species & FG & HG & PCCAC & РССРC & $\mathbf{T P}$ & Uses & Exo & otic \\
\hline Rutaceae & Citrus limetta (Risso.) & & $\mathrm{x}$ & & $x$ & & $\mathrm{~B}, \mathrm{G}$ & 2 & $\mathrm{x}$ \\
\hline Rutaceae & Citrus sinensis (L.) Osbeck & & $\mathrm{x}$ & $x$ & $x$ & $x$ & $\mathrm{~A}, \mathrm{~B}, \mathrm{D}, \mathrm{F}, \mathrm{G}, \mathrm{H}, \mathrm{I}$ & 7 & $\mathrm{x}$ \\
\hline Rutaceae & Murraya paniculata (L.) Jack & & $\mathrm{x}$ & & & & $\mathrm{H}$ & 2 & $\mathrm{x}$ \\
\hline Rutaceae & Zanthoxylum sp. (Mill.) & & & & & $x$ & $C, D, F$ & 4 & \\
\hline Rutaceae & Citrus reticulata (Blanco.) & & $\mathrm{x}$ & $\mathrm{x}$ & & & $A, B, C, F, G$ & 5 & $x$ \\
\hline Salicaceace & Pleuranthodendron lindenii (Turcz.) Sleume & $x$ & & & & & C, F & 1 & \\
\hline Salicaceae & Salix humboldtiana (Willd.) & & & & & $x$ & C, D, F, G, I & 5 & \\
\hline Sapindaceae & Cupania glabra (Sw.) & $\mathrm{x}$ & & & $\mathrm{x}$ & & $\mathrm{C}$ & 2 & \\
\hline Sapindaceae & Litchi chinensis (Sonn.) & & $\mathrm{x}$ & & $\mathrm{x}$ & & $\mathrm{B}, \mathrm{H}, \mathrm{I}$ & 3 & $x$ \\
\hline Sapotaceae & Manilkara zapota (L.) P.Royen & & $\mathrm{x}$ & & $\mathrm{x}$ & $\mathrm{x}$ & $\mathrm{B}, \mathrm{I}$ & 2 & \\
\hline Sapotaceae & Pouteria campechiana (Kunth) Baehni & & & & $\mathrm{x}$ & & $\mathrm{B}, \mathrm{I}$ & 2 & \\
\hline Sapotaceae & Pouteria sapota (Jacq.) H. E. Moore \& Stearn & & $\mathrm{x}$ & & $x$ & $\mathrm{x}$ & $\mathrm{A}, \mathrm{B}, \mathrm{C}, \mathrm{F}, \mathrm{I}$ & 5 & \\
\hline Scrophulariaceae & Buddleja cordata (Kunth.) & & $\mathrm{x}$ & & & & G & 1 & \\
\hline Solanaceae & Cestrum sp. (L.) & $\mathrm{x}$ & & & & & & & \\
\hline Solanaceae & Erianthuri sp. (Juss.) & $\mathrm{x}$ & $\mathrm{x}$ & & & & & & \\
\hline Ulmaceae & Ampelocera hottlei (Standl.) & & & & $x$ & & $\mathrm{~F}$ & 1 & \\
\hline Urticaceae & Cecropia obtusifolia (Bertol.) & $x$ & & & & & $\mathrm{~F}, \mathrm{G}$ & 2 & \\
\hline Urticaceae & Urera caracasana (Jacq.) Gaudich. ex Griseb. & $x$ & $\mathrm{x}$ & & & & G & 1 & \\
\hline Urticaceae & Urera corallina (Liebm.) Wedd. & $x$ & & & & & $\mathrm{~F}$ & 1 & \\
\hline Total: 50 & 115 & 48 & 68 & 12 & 45 & 51 & & 256 & 24 \\
\hline
\end{tabular}




\section{References}

1. Moreno-Calles, A.I.; Toledo, V.M.; Casas, A. Los sistemas agroforestales tradicionales de Mexico: Una aproximacion biocultural. Bot. Sci. 2013, 91, 375-398. [CrossRef]

2. Skutsch, M.; Mas, J.F.; Bocco, G.; Bee, B.; Cuevas, G.; Gao, Y. Deforestation and land tenure in Mexico: A response to Bonilla-Moheno et al. Land Use Policy 2014, 39, 390-396. [CrossRef]

3. Braat, L.C.; de Groot, R. The ecosystem services agenda: Bridging the worlds of natural science and economics, conservation and development, and public and private policy. Ecosyst. Serv. 2012, 1, 4-15. [CrossRef]

4. Challenger, A.; Dirzo, R. Factores de cambio y estado de la biodiversidad. In Capital Natural de México, Vol II: Estado de Conservación y Tendencias de Cambio; CONABIO, Ed.; CONABIO: Mexico City, Mexico, 2009; Volume 2, pp. 37-73.

5. Sarukhan, J.; Koleff, P.; Carabias, J.; Soberon, J.; Dirzo, R.; Llorente-Bousquets, J.; Halffter, G.; Gonzalez, R.; March, I.; Mohar, A.; et al. Capital Natural de Mexico. Sintesis: Conocimiento Actual, Evaluacion y Perspectivas de Sustentabilidad; CONABIO: Mexico City, Mexico, 2009.

6. The World Bank Rural Poverty Headcount Ratio at National Poverty Lines (\% of Rural Population). Available online: http:/ / data.worldbank.org/indicator/SI.POV.RUHC (accessed on 30 June 2017).

7. USAID. USAID Country Profile Mexico; USAID: Washington, DC, USA, 2011.

8. Caballero, J.; Cortés, L. Percepción, Uso y manejo tradicional de los recursos vegetales en México. In Plantas, Cultura y Sociedad. Estudios Sobre la Reación Entre Seres Humanos y Plantas en Los Albores Del Siglo XXI; Rendón Aguilar, B., Rebollar Domínguez, S., Caballero Nieto, J., Martínez Alfaro, M.Á., Eds.; Universidad Autónoma Metropolitana, Secretaría de Medio Ambiente, Recursos Naturales y Pesca: Mexico City, Mexico, 2001; pp. 79-100, ISBN 9706547827.

9. Wiersum, K.F. Indigenous explotation and management of tropical forest resources: An evolutionary continuum in forest-People interactions. Agric. Ecosyst. Environ. 1997, 63, 1-16. [CrossRef]

10. Nair, P. Social consideration of agroforestry systems. In An Introduction to Agroforestry; Nair, P., Ed.; International Centre for Agroforesty, Kluwer Academic Publishers: Dordrecht, The Netherlands, 1993; pp. $413-425$.

11. Wiersum, K. From natural forest to tree crops, co-domestication of forests and tree species, an overview. Neth. J. Agric. Sci. 1997, 45, 425-438.

12. Schroth, G.; da Fonseca, G.A.B.; Harvey, C.A.; Gascon, C.; Vasconcelos, H.L.; Izac, A.-M.N. Agroforestry and Biodiversity Conservation in Tropical Landscapes; Island Press: Washington, DC, USA, 2004; ISBN 1559633573.

13. Michon, G. Domesticating Forests: How Farmers Manage Forest Resources; Institut de Recherche pour le Développement, Center for International Forestry Research, The World Agroforestry Centre and ICRAFSoutheast Asia Regional Office: Jakarta, Indonesia, 2005; ISBN 979-3361-65-4.

14. Belcher, B.B.; Michon, G.; Angelsen, A.; Ruiz-Pérez, M.; Asbjørnsen, H. Cultivating (in) tropical forests? The evolution and sustainability of systems of management between extractivism and plantations. In Workshop "The Evolution and Sustainability of Systems of Management"; ETFRN, Ed.; Kraemmervika: Lofoten, Norway, 2000; pp. $9-40$.

15. Scherr, S.J.; McNeely, J.A. Biodiversity conservation and agricultural sustainability: Towards a new paradigm of "ecoagriculture" landscapes. Philos. Trans. R. Soc. B Biol. Sci. 2008, 363, 477-494. [CrossRef] [PubMed]

16. Schroth, G.; Harvey, C.A.; Vincent, G. Complex Agroforests: Their structure, diversity and potential role in landscape conservation. In Agroforestry and Biodiversity Conservation in Tropical Landscapes; Schroth, G., da Fonseca, G.A.B., Harvey, C.A., Gascon, C., Vasconcelos, H.L., Izac, A.-M.N., Eds.; Island Press: Washington, DC, USA, 2004; Volume 10, pp. 227-260, ISBN 1-55963-356-5.

17. German, L.; Keeler, A. Hybrid institutions?: Applications of common property theory beyond discrete tenure regimes. Int. J. Commons 2009, 4, 571. [CrossRef]

18. Ellis, E.A.; Romero Montero, J.A.; Hernández Gómez, I.U. Deforestation Processes in the State of Quintana Roo, Mexico. Trop. Conserv. Sci. 2017, 10, 1-12. [CrossRef]

19. Romero-Manzanares, A.; Aguirre-Rivera, R. El papel del hombre en la evolución de los piñoneros Americanos. Agrociencia 1999, 33, 473-481.

20. Romero-Manzanares, A.; García-Moya, E. Estabilidad y elasticidad de las poblaciones y comunidades biológicas. Agrociencia 1999, 33, 227-234. 
21. Vásquez Zárate, S.R.; Ruíz Gordillo, J.O.; Sánchez y Gándara, A. (Eds.) "Los Ídolos", Misantla: Biodiversidad y Cultura Ancestral; Asociación Para el Desarrollo Integral de la Región de Misantla A.C.: Veracruz, Mexico, 2012.

22. Harris, D.R. An evolutionary continuum of people-plant interaction. In The Emergence of Agriculture: A Global View; Denham, T., White, J.P., Eds.; Routledge: London, UK, 2007; pp. 26-45, ISBN 9780415404457.

23. Environmental Systems Research Institute. ESRI ArcGIS Desktop: Release 10.4; Environmental Systems Research Institute: Redlands, CA, USA, 2016.

24. Lamprecht, H. Silviculture in the Tropics: Tropical Forest Ecosystems and Their Tree Species-Possibilities and Methods for Their Long-Term Utilization; Deutsche Gesellschaft für Technische Zusammenarbeit: Eschborn, Germany, 1989; ISBN 388085422X.

25. Salmon, A. Walking the Talk: How Participatory Interview Methods Can Democratize Research. Qual. Health Res. 2007, 17, 982-993. [CrossRef] [PubMed]

26. De Groot, R.S.; van der Meer, P. Quantifying and valuing ecosystem services provided by plantation forests. In Ecosystem Goods and Services from Plantation Forests; Baauhus, J., van der Meer, P., Kanninen, M., Eds.; Earthscan: New York, NY, USA, 2010; pp. 16-42, ISBN 1136532285; 9781136532283.

27. Holzman, D.C. Accounting for nature's benefits: The dollar value of ecosystem services. Environ. Health Perspect. 2012, 120, a152-a157. [CrossRef] [PubMed]

28. Kumar, B.M.; Takeuchi, K. Agroforestry in the Western Ghats of peninsular India and the satoyama landscapes of Japan: A comparison of two sustainable land use systems. Sustain. Sci. 2009, 4, 215-232. [CrossRef]

29. Brandt, R.; Zimmermann, H.; Hensen, I.; Mariscal Castro, J.C.; Rist, S. Agroforestry species of the Bolivian Andes: An integrated assessment of ecological, economic and socio-cultural plant values. Agrofor. Syst. 2012, 86, 1-16. [CrossRef]

30. Bennett, B.C.; Prance, G.T. Introduced plants in the indigenous pharmacopoeia of northern South America. Econ. Bot. 2000, 54, 90-102. [CrossRef]

31. De Albuquerque, U.P.; Monteiro, J.M.; Ramos, M.A.; de Amorim, E.L.C. Medicinal and magic plants from a public market in northeastern Brazil. J. Ethnopharmacol. 2007, 110, 76-91. [CrossRef] [PubMed]

32. Phillips, O.; Gentry, A.H. The useful plants of Tambopata, Peru: II. Additional hypothesis testing in quantitative ethnobotany. Econ. Bot. 1993, 47, 33-43. [CrossRef]

33. Wiersum, K.F.F. Forest gardens as an "intermediate" land-use system in the nature-culture continuum: Characteristics and future potential. Agrofor. Syst. 2004, 61, 123-134.

34. Food and Agriculture Organization (FAO). Ecocrop. Available online: http:/ /ecocrop.fao.org/ecocrop/srv/ en/home (accessed on 30 June 2017).

35. Lascurain-Rangel, M.; Avendaño, S.; del Amo, S.; Niembro, A. Guía De Frutos Silvestres Comestibles en Veracruz; Fondo Sectorial para la Investigación, el Desarrollo y la Innovación Tecnológica Forestal, CONAFOR-CONACyT: Mexico City, Mexico, 2010; ISBN 9786077579199.

36. Lascurain-Rangel, M.; López, C.; Zamora, P. Production chain of Oecopetalum mexicanum ("cahichín"): A tropical fruit tree from Mexico. Acta Hortic. 2009, 806, 519-524. [CrossRef]

37. López-Acosta, J.C.; Lascurain-Rangel, M.; López Binnqüist, C.; Covarrubias, M. Structure and floristic composition of forest management systems associated with the edible fruit tree Oecopetalum mexicanum in the Sierra de Misantla, Veracruz, Mexico. Econ. Bot. 2014, 68, 44-58. [CrossRef]

38. Álvarez-Buylla Roces, M.E.; Lazos Chavero, E.; García-Barrios, J.R. Homegardens of a humid tropical region in Southeast Mexico: An example of an agroforestry cropping system in a recently established community. Agrofor. Syst. 1989, 8, 133-156. [CrossRef]

39. Van der Wal, H.; Bongers, F. Biosocial and bionumerical diversity of variously sized home gardens in Tabasco, Mexico. Agrofor. Syst. 2013, 87, 93-107. [CrossRef]

40. Lascurain-Rangel, M.; López Binnqüist, C.; Emery, M.; Maganda, C. Culture and environment in the Sierra de Misantla, Veracruz, Mexico: The case of Oecopetalum mexicanum. Madera Bosques 2016, 22, 11-21. [CrossRef]

41. Burgos-Hernández, M.; Castillo-Campos, G.; Vergara Tenorio, M.D.C. Potentially useful flora from the tropical rainforest in central Veracruz, Mexico: Considerations for their conservation. Acta Bot. Mex. 2014, 1, 55. [CrossRef]

42. Piotto, D.; Váquez, E.; Montagnini, F.; Kanninen, M. Pure and mixed forest plantations with native species of the dry tropics of Costa Rica: A comparison of growth and productivity. For. Ecol. Manag. 2004, 190, 359-372. [CrossRef] 
43. Pandey, D. Multifunctional agroforestry systems in India. Curr. Sci. 2007, 92, 455-463.

44. SEMARNAT Norma Oficial Mexicana. Protección Ambiental-Especies Nativas de México De Flora y Fauna Silvestres. Categorias de Riesgo y Especificaciones Para su Inclusión, Exclusión o Cambio; Diario Oficial: Ciudad de Mexico, Mexico, 2010; p. 78. 